\title{
neofilolog
}

Czasopismo Polskiego Towarzystwa Neofilologicznego

ISSN 1429-2173, elSSN 2545-3971, 2020, NR 54/1, 27-45

http://dx.doi.org/10.14746/n.2020.54.1.3

http://poltowneo.org/

\section{Monika todej}

Uniwersytet Pedagogiczny im. Komisji Edukacji Narodowej w Krakowie https://orcid.org/0000-0001-5348-4115 monika.lodej@up.krakow.pl

\section{APPLICATION OF INCLUSIVE DESIGN PRINCIPLES TO TESTING EFL DYSLEXIC STUDENTS}

\begin{abstract}
There are two main challenges with inclusive testing of EFL students with dyslexia. First, application of inclusion may, paradoxically, involve exclusion of SEN students. Second, there is evidence for inconsistent policies relating to internal and external testing practices. The present paper reports on the application of inclusive design principles to the language testing of EFL students with dyslexia. Specific cognitive demands characteristic of dyslexia are mapped against both the types of accommodations made for SEN students and the principles of inclusive design. The results show a high degree of applicability of inclusive design principles in testing EFL students with dyslexia. Specifically, the data point to a strong alignment between presentation and response accommodations and five areas of weaknesses in dyslexia. The review concludes with a discussion on the benefits and limitations of inclusive testing in dyslexia. It is hoped that this study will advise testing boards, EFL teachers, as well as education and assessment services on the application of inclusive practices to testing EFL dyslexic learners.
\end{abstract}

Keywords: inclusive design principles, dyslexia, language testing, EFL

Słowa kluczowe: projektowanie inkluzywne, dysleksja, testy językowe, angielski jako język obcy 


\section{Introduction}

In 1945 the League of Nations adopted the Universal Declaration of Human Rights (The United Nations, 1948). In the field of education, Article 26 of the Declaration states that "(1) Everyone has the right to education" and that "(2) Education shall be directed to the full development of the human personality". The word inclusion was not used in this document per se, however, the underlying concept of inclusion is clearly implied in this Article. As "the European way is also the United Nations' way" (EEAS, 2018: 1) the European Council, European Parliament and European Commission adopted the European Pillar of Social Rights in 2017 which stresses that "everyone has the right to quality and inclusive education, training and lifelong learning in order to maintain and acquire skills that enable them to participate fully in society and successfully manage transitions in the labour market". Inclusion is defined here with reference to education that is equal regardless of gender, racial or ethnic origin, religion or belief, disability or age of the EU citizen.

Kisanji (1999) notes that the history of inclusiveness in Europe began with exclusion movements. People with disabilities were treated as a threat to the community and were alienated or excluded for that reason. The otherness of the disabled would instill fear in the typically developing members of society to the extent that, in some cases, they applied protective measures which, in extreme cases, aimed at eliminating people with disabilities from society (Adams, Bell, 2016). People with physical and intellectual disability were also used for entertainment or as objects of ridicule e.g. as court jesters (Bagrieli, Shapiro, 2012). In 17th century London mentally disabled patients of the Bethlem Hospital were placed in a showroom so that the public could watch them chained and caged (Arton, 1998). It was not until the 18th century when the rights for social inclusion of persons with disabilities began to be recognized. Consequently, Charles-M ichel de I'Épée, Valentin Haüy and Jean $M$ arc Gaspard Itard, the pioneers of educational inclusion, paved the way for the establishment of the first schools for people with disabilities.

\section{Inclusive education}

Like social inclusion movements, educational inclusion evolved from educational exclusion. The world systems that govern the education of people with special needs have come a long way, from segregating students to mainstreaming them (Reddy, 2012). From a historical perspective, this move started with a tradition of isolating students with special needs from their typically developing peers. In the 19th century when the first attempts to educate 
students with disabilities were recorded in private or public institutions, self contained-classrooms within schools were introduced (Gordon et al., 2014). The scope and degree of educational inclusion is reflected in interpretation of the term inclusiveness. The debate over the terms and conditions for educational inclusion has been ongoing since its beginnings. Haug (2017: 207) observes that "inclusion is strongly value-and ideology-driven, in the same category as other similar concepts, such as democracy and social justice". The implementation of inclusion, in a natural way, differs between countries, counties and individual schools. For the clarity of this paper the term educational inclusion will follow the definition proposed at the World Conference on Special Needs Education and recorded in the Salamanca Statement. It recognizes a child's unique characteristics, interests, abilities, and learning needs and proclaims that "those with special education needs must have access to regular schools which should accommodate them with a child-centered pedagogy capable of meeting those needs" (UNESCO, 1994: viii).

The current trends in the EU towards inclusive education are geared to three approaches i.e. the one-track approach, the two-track approach and the multi-track approach (M erijer, et al., 2003). The one-track approach assumes that inclusive practices are implemented and offered within mainstream education. This approach is followed by Spain, Greece, Italy, Portugal, Sweden, Iceland, Norway and Cyprus. The two-track approach is built on the existence of two distinct educational systems consisting of special schools or special classes and mainstream schooling. In this system students with special educational needs (SEN) are usually referred to special schools and special classes whose programs do not follow the mainstream curriculum. These systems are controlled by separate laws and there are separate regulations for mainstream and SEN education. Interestingly, SEN students who are enrolled in mainstream schooling and benefit from special services follow a different curriculum than their non-disabled peers. This dual system operates in Switzerland and in Belgium. The third approach, referred to as multi-track, is characterized by availability of various modes and services that support inclusion. These are available through mainstream and special needs education systems. This approach has been implemented in Austria, the Czech Republic, Denmark, Estonia, Finland, France, Ireland, Latvia, Liechtenstein, Lithuania, Luxembourg, Poland, Slovakia, Slovenia and the United Kingdom.

The literature on the subject informs us about various general inclusive principles (Karten, 2015: 23; Lawrence-Brown, Sapon-Shevin, 2015: 4-9; Conn, 1992 in Kearney, 1996: 5) as well as about specific relevant practices (Pfeiffer, Reddy, 1999; Nes, Strømstad, 2003; Mc Leskey, 2019). For the European context the European Agency for Development in Special Needs Education 
(Watkins, 2009: 15-18) published a list of key principles in inclusive education that declare the following: a) inclusion concerns a wider range of learners than those identified as having special educational needs, b) access to mainstream education alone is not enough, $c$ ) it should be ensured that all teachers are trained, and d) support should be given to allow the participation of learners and their parents in educational decision-making. In order to meet the diverse needs of SEN students the following set of strategies is promoted: cooperative teaching, co-operative learning, collaborative problem solving, and heterogeneous grouping. The agenda for inclusive classroom practices includes reference to assessment for learning, differentiation, development of personalized learning approaches and development of an Individual Education Plan (IEP). What seems to be missing from this report is direct reference to the concepts of instructional and curricular adaptations, as well as to peermediated instruction and intervention (Bui et al., 2010).

\section{Inclusive design}

Inclusive design may be broadly defined as "the design of products or environments to be usable by all people, to the greatest extent possible, without the need for adaptation or specialized design" (Mace in Steinfeld, 2010: 1). Currently, the term inclusive design is used interchangeably with universal design (Clarkson et al., 2007: 8) and design for all (EDF, 2019). The distinction lies in the origins of these terms and depends on the part of the world where these designations are used.

The concept of universal design originated in the United States. It was coined by architect and designer Ronald L. Mace who advocated for barrierfree design that meets the needs of all people, regardless of their age or ability. By contrast, the term inclusive design is used mainly in the United Kingdom and Europe. It was precisely defined in 2000 by the UK Government (M yerson et al., 2016). The premise of the concept lies in focus on designing mainstream products, instead of products for marginalized groups. The third term design for all was postulated by the European Commission (EIDD, 2004) and is used in continental Europe and Scandinavia. For the purpose of this paper, which is rooted in European contexts, the term inclusive design will be used throughout the present discussion. The definition of inclusive design itself did not specify the tools or approaches that would allow implementation of the concept. To fill this gap, experts who worked for the center of Universal Design in North Carolina, USA developed, what is now known as the Principles of Universal Design (Perrson et al.,2014). According to the Center for Universal Design, the Seven Principles (see Table 1) "may be applied to evaluate existing designs, guide 
Application of inclusive design principles to testing EFL dyslexic students

the design process and educate both designers and consumers about the characteristics of more usable products and environments" (NDA, 2012).

\begin{tabular}{|l|l|}
\hline Principle & Description \\
\hline 1. Equitable Use & The design is useful and marketable to people with diverse abilities. \\
\hline 2. Flexibility in Use & $\begin{array}{l}\text { The design accommodates a wide range of individual preferences } \\
\text { and abilities. }\end{array}$ \\
\hline $\begin{array}{l}\text { 3. Simple and Intuitive } \\
\text { Use }\end{array}$ & $\begin{array}{l}\text { Use of the design is easy to understand, regardless of the user's ex- } \\
\text { perience, knowledge, language skills, or current concentration level. }\end{array}$ \\
\hline $\begin{array}{c}\text { 4. Perceptible } \\
\text { Information }\end{array}$ & $\begin{array}{l}\text { The design communicates necessary information effectively to the } \\
\text { user, regardless of ambient conditions or the user's sensory abilities. }\end{array}$ \\
\hline $\begin{array}{c}\text { 5. Tolerance for Error } \\
\text { The design minimizes hazards and the adverse consequences of ac- } \\
\text { cidental or unintended actions. }\end{array}$ \\
\hline $\begin{array}{c}\text { 6. Low Physical Effort } \\
\text { 7. Size and Space for } \\
\text { Approach and Use }\end{array}$ & $\begin{array}{l}\text { The design can be used efficiently and comfortably and with a mini- } \\
\text { mution, and use regardless of user's body size, posture, or mobility. }\end{array}$ \\
\hline
\end{tabular}

Table 1: Principles of universal (inclusive) design (after Steinfeld, 2010: 2, and NDA, 2012).

\section{Standardized testing}

In the majority of the EU member states standardized assessment and testing have been imposed on teachers and schools by either school governing bodies, or government regulations. A standardized test is generally understood as a test that is administered and scored in a consistent or standard manner. The Glossary of Education Reform (2015) defines the term standardized test as "any form of test that (1) requires all test takers to answer the same questions, or a selection of questions from a common bank of questions, in the same way, and that (2) is scored in a "standard" or consistent manner, which makes it possible to compare the relative performance of individual students or groups of students". Thus, the information collected serves school decisionmakers in the making of judgments on the quality of teaching services by individual teachers, schools and districts. It is a common practice that lists ranking high and low performing schools are published annually. Ratings which are based on the results of mandated tests impact the educational landscape in several ways. Firstly, they inform governmental units on the quality of teaching and allow them to undertake corrective measures to support schools. Secondly, the data set offers school principals an insight into the quality of the teaching of individual teachers. Thirdly, they may help parents and students to make a decision about which school to enroll their child. Lastly, the results in the UK obtained from SATs and A-levels are marked as prerequisites for school or university admission. 
At the same time, it has often been debated if the use of standardized testing improves education and whether tests are fair and objective tools for measuring students' learning. The controversies over standardized testing include, among others, lack of inclusiveness (Pohl et al., 2016), narrowing the curriculum by teaching to the test rather than other skills (Linn, Herman, 1997 in Bhattacharyya, Clark, 2013; Richardson, Wheeless, 2009; Wallace, Irons, 2010), rise in anxiety level of students and teachers (Smith, 1991) as well as pushing students out of school and driving teachers out of the profession (Hout, Elliott, 2011 in Evans, Howarth, 2019). It is to be observed that the current design of standardized tests hardly ever recognizes the needs of SEN students and their cognitive limitations. Dolezalek and Sayre (2009: 20) point to the fact that "while the test is the same for every student who takes it, not all students are the same". Despite the fact that the school educational trajectory of SEN students has been widely documented in research, it still tends not to be fully recognized by authors of standardized tests. In other words test formats are designed with the profile of an average student in mind. The description of the procedure used to evaluate the reliability of PISA tests can serve as an example of insufficient use of the SEN population in the planning and preparation of test formats. The report by $\operatorname{OECD~(2012:~221)~reveals~that~SEN~}$ students were underrepresented in the study, due to the independent decision of testers not to include students if their learning deficits were considered to constitute a barrier.

\section{Purpose of the study}

Formal assessment and testing of students with SEN is motivated by two approaches, that is by accommodations, or by modifications of tests (ADE, 2005; Darrow, 2007; Twachtman-Cullen, Twachtman-Bassett, 2011). These approaches differ in respect to the scope and purpose of adaptations. Accommodations are provisions made in how a student is assessed or demonstrates learning, whereas modifications are changes in what a student is expected to learn or demonstrate. Accommodations are designed for students with mild learning disabilities i.e. dyslexia, ADHD or other learning difficulties, while modifications are applied in assessment and testing of students who represent severe learning difficulties such as Autism spectrum disorder (ASD), Down syndrome or intellectual disability. In the Polish context the division is marked by the type of SEN documentation and school type. Accommodations are given to SEN students with a SEN statement (Polish opinia) who are enrolled in the mainstream education system. M odifications, on the other hand, are offered to SEN students with a SEN certificate (Polish orzeczenie) who are 
educated in special education schools or units. The current study looks at students with dyslexia who hold a dyslexia statement. These students are also enrolled in mainstream education and learn English as a FL. To be specific, the study aims to analyse and map the alignment between inclusive design principles, the type of test accommodations and cognitive deficits in dyslexia. It is hoped that this discussion might fill the gap in current research by exploring the application of inclusive design principles to the testing of EFL dyslexic learners.

\section{Method}

\subsection{Study design}

The present study employs a literature review methodology and takes, in part, a scoping review approach (Finkelstein et al., 2019). A literature review was conducted regarding educational inclusion, and inclusive design, in order to develop frames for a discussion on inclusive testing. In contrast, a scoping review was undertaken to answer the question of how the inclusive design principles can be used in testing students with dyslexia. This question was exploratory in nature and aimed to map key concepts, and identify gaps in the research relating to the benefits and limitations of the application of inclusive design principles to the testing of students with dyslexia (Colquhoun et al., 2014 in Dijkers, 2015: 3). Firstly, an overview of the literature was conducted for the concepts inclusion, inclusive education, inclusive design and standardized testing in order to specify their applicability and limitations in relation to the research question. Then, a mapping procedure was applied to track alignment between inclusive design principles, the type of test accommodations and cognitive deficits in dyslexia.

The first stage of the search process was conducted with the use of four electronic databases: EBSCO, Research Gate, Google Scholar, and Google Books. In addition, an open search was carried out to identify applicationbased publications on the inclusive testing of EFL students. The terms used in the initial queries included the following key words: testing, SEN, dyslexia, accommodations, inclusive, and EFL. This was followed by an analysis of the title, abstract and key words with the exception of Google Books results. For Google Books titles and the short descriptions were analysed. Finally, a screening procedure was conducted, aimed at identifying studies which offered reports on the inclusive testing of language learners with dyslexia. Of 100 records identified in the database set eleven such papers were included in the review. In the open Internet search 169 records were identified, out of which six were included for further discussion. Both the articles and application-based publications were 
included in the review on the condition that they met the following criteria: (1) they focused on testing language skills in students with SEN or dyslexia, (2) made reference to the classroom setting, and (3) were published in English.

\subsection{Procedures}

To investigate the degree to which the principles of inclusive design could be used in the construction of EFL language proficiency tests, a mapping procedure was applied. It aimed to track the alignment between inclusive design principles, types of test accommodations and cognitive deficits in dyslexia. This approach followed a two-step procedure to investigate the alignment between inclusive design principles and types of SEN test accommodations and the alignment between the types of SEN test accommodations and cognitive deficits in dyslexia.

\subsection{Results}

\subsubsection{Alignment between principles of inclusive design and the type of test accommodations}

The analysis of relations between the principles of inclusive design and the types of test accommodations (cf. Appendix A) allows one to conclude that in reference to the broad SEN population only the first five inclusive design principles can be adopted for use in standardized language progress tests. These principles include Equitable Use, Flexibility in Use, Simple and Intuitive Use, Perceptible Information, and Tolerance for Error. It can be noted that the design approaches that are beneficial for people with diverse abilities constitute the key aspects of inclusive design. This methodology is referred to as Equitable Use and aims to provide the same means of use for all users, making the means of use identical whenever possible, or applying equivalent solutions when identical rendition is not possible. The approach of Equitable Use avoids the segregation or stigmatization of users and makes the design appealing to all users. Consequently, it complies with presentation and response accommodations, such as giving increased spacing between test items, using non-serif font, limiting the number of visual distractors and offering alternative ways of providing answers.

Flexibility in Use is another design principle which emphasizes accommodation of the wide range of individual preferences and abilities which constitute a core of SEN adaptations. This regulates design decisions that facilitate the user's accuracy and precision, as well as provide adaptability to the user's pace of work. These guiding principles can be implemented in practice with the use of presentation, response and timing, or by scheduling accommodations 
by providing visual cues, or templates, or by giving extended time for the test. However, the guidelines that relate to provision in choice of methods of use, and accommodating right- or left-handed access, could be utilized only in computer-based testing. Similarly, the principle of Simple and Intuitive Use that is an application of design which is easy to understand regardless of the user's experience, knowledge, language skills, or current concentration level, relates closely to the underpinnings of SEN test accommodations. Its guidelines promote the undertaking of design actions which eliminate unnecessary complexity and remain consistent with user expectations and intuition. The approach of Simple and Intuitive Use accommodates a wide range of literacy and language skills, as well as attempts to arrange information consistent with its importance. The principles discussed above reflect the central assumption of test design that defines how something can be tested. However, it is also essential to stress the importance of the provision of effective prompting and feedback during and after task completion which seem to apply mainly to assessment for learning, while standardized tests are examples of assessment of learning. When Simple and Intuitive Use is mapped against test accommodation it can be observed that the principles align with presentation, response and timing/scheduling accommodations which relate to the provision of ontask/focusing prompts, permitting answers to be recorded directly into the test booklet, or breaking large assignments into smaller tasks.

Design that minimizes hazards and the adverse consequences of accidental or unintended actions is included in the principle of Perceptible Information, which sets the design environment as one which communicates information to the user accurately, regardless of the user's sensory conditions. This includes, among others, the use of varied communication modes, such as pictorial, verbal or tactile modes, and provides legibility and adequate contrast between essential information and its background. It also differentiates structural elements in ways which can be described accurately and provides compatibility with the variety of techniques or devices that are used by people with sensory limitations.

These design prescriptions lie at the core of presentation, response, timing/scheduling and setting accommodations that aim to provide visual cues when possible, limit the number of visual distractors, permit answers to be recorded directly into the test booklet, or allow a change of location in order to access special equipment. Along the same lines, the principle of Tolerance for Error aims at designs that minimize the consequences of accidental or unintended actions. Consequently, it promotes design arrangements which discourage unconscious actions in tasks that require vigilance and caution. The negative effects of unintended actions can be compensated by the application of presentation, response, timing/scheduling and setting accommodations 
evident in increased spacing between test items, monitored placement of student responses on the answer sheet, allowance of frequent breaks and the organization of the test in a quiet location so as to reduce distractions.

In contrast to the high applicability of the first five inclusive design principles to testing accommodations for SEN students, the remaining two i.e. Low Physical Effort and Size and Space for Approach and Use, seem to be of limited use in pen and paper tests. Students are limited by the setting and space conditions especially in internal (classroom based) tests. The provision of adequate space for the use of assistive devices, or personal assistance, which allows users to maintain a neutral body position at a classroom desk is impossible for a regular mainstream school to offer.

\subsubsection{Alignment between the type of testaccommodations and areas of weaknesses in dyslexia}

When the types of general SEN accommodations are mapped against the areas of weaknesses in dyslexia (cf. Appendix B) a number of discrepancies in the requirements can be observed. First, the mapping shows that these are only the presentation and response accommodations align in full with the deficits characteristic for dyslexia. The presentation accommodations are aimed at allowing students to access information in ways which do not require students to rely solely on visual processing of standard print size and shape. In addition, accommodations should allow for alternative modes of access which offer a combination of visual and auditory stimuli. On the other hand, response accommodations allow students to complete tests and activities in different ways, or to solve and organize problems using some type of assistive device. These accommodations answer to the needs of dyslexic students which result from deficits in short term memory, phonological skills, sequencing and structuring information, and perception.

Weaknesses in short memory cause students to have problems with copying down correctly, keeping track of ideas when speaking, listening or writing, following the sense of a passage while reading, or multi-tasking. To compensate for these deficits test accommodations for dyslexic students include, among others, a reduced number of elements which can interfere with short term and working memory, as well as the provision of memory aids and visual supports. Additionally, it is important for information to be divided into smaller instructional units and for complex instructions to be reworded by means of short sentences. A spelling bank may also be an important reference tool. Similarly, weaknesses in phonological skills make students struggle with spelling, understand long words and maintain appropriate levels of reading 
accuracy. To accommodate for these difficulties tests are arranged to pair visuals with oral instructions, using highlighting for key words and concepts. M oreover, difficulty with sequencing and structuring information causes problems with writing and copying words accurately. Dyslexic students have difficulty following and understanding instructions, structuring essays, taking clear notes, or completing filling-in tasks. When presentation and response accommodations are implemented they may include the use of the cloze method and provision of templates. Poor visual perception may result in the student misreading words, losing the place while reading, missing out words or lines, rereading, or ignoring diacritics. To compensate for these weaknesses test accommodations may offer a reduction of extraneous visual stimuli on a page by highlighting the target stimulus, and by provision of visual markers to guide the student. Reducing the visual clutter in test sheets appears to be a general rule for this type of accommodation.

Apparently, timing and scheduling accommodations are not normally used in testing the language proficiency of dyslexic students. Frequent breaks are not obligatory or available and students are not encouraged to take subtests in a different order during test sessions. Extended the allotted time for taking a test is the only overlapping testing adjustment. The largest discrepancies are observed in setting accommodations. These refer to the place where tests are taken, but they are not usually obligatory for, or are not offered to, dyslexic students. As a rule, the location of testing remains the same, as the test behavior of students with dyslexia, on average, does not distract other tests takers and special writing equipment is rarely offered, since not all dyslexic students are concurrently dysgraphic.

In view of the above discussion of the types of tests accommodations it can be argued that presentation and response accommodations contribute mainly to the validity of the testing of students with dyslexia. Dyslexic students cannot access a test and perform well if their perception is hampered by visual obstacles, such as serif font, or font which is too small, single spacing between lines, or multiple types of font within one task. It becomes evident that the test results may reflect a student's ability (or inability) to decode print, or deal with test layout, rather than their subject knowledge. Further, a test loses its validity when response accommodations are not recognized in the format of the tests e.g. spelling is used to evaluate grammar knowledge, or if it is compulsory for students to transfer answers onto an answer sheet, or if vocabulary is measured with the use of comprehension of a text. Test results obtained by means of an invalid test format do not inform the teacher of a student's progress in language skills, as this is blocked by the student's weaknesses in writing, or by inaccurate processing of a written text. 


\section{Conclusions and discussion}

The present study accounts for the model of full inclusion of EFL dyslexic students in foreign language education. This model discourages exclusion of students by arbitrary decisions which regulate what the student should know, learn and what knowledge they should demonstrate. At the same time, it stands in opposition to the use of separate classrooms, narrowed access to the curriculum, and modified rather than accommodated tests. Instead, it calls for inclusion carried out by accommodating services which meet the needs of dyslexic students in the way that follows the principles of inclusive design.

Moreover, the current research shows that in the case of dyslexia, inclusive design in testing can be achieved by application of presentation, and response accommodations which in consequence positively affect the timing of a test. First, adaptations that refer to timing (offering extended time) seem to be the only condition which does not conform to the concept of full inclusion. Interestingly, with a redesign of testing materials students can perform on a task and demonstrate knowledge in the same time as their non-dyslexic peers. This additional time can be compensated by a decrease in the cognitive workload. This, in turn, can be achieved by the application of presentation and response accommodations. Therefore, EFL language proficiency tests would not violate any of the principles of inclusive design.

It is clear from the discussion above that inclusive and universal EFL test formats are technically workable. The move towards inclusion of dyslexic students has already been recognized by some ELT publishers, who offer two versions of tests, i.e. for regular achievers and for students with dyslexia. In this approach to inclusion emphasis is put on design that would allow dyslexic students to demonstrate their knowledge with the use of separate tests. Interestingly, the availability of the dyslexia-friendly tests raises several concerns regarding fairness in testing and lack of consistency with formats of external test. The first concern seems to be a call for an inclusive design of English progress tests which would not segregate regular achievers and dyslexic students and would support fair testing and marking. Another concern relates to the dissonance between testing accommodations available to dyslexic students in internal and external tests.

This study, being exploratory in nature, raises a number of suggestions for future research, both in terms of concept validation and application of tests. First, there is a need to challenge research on the inclusive testing of different categories of EFL SEN students. Second, this study may serve as a platform for further discussion on the model of inclusion that allows dyslexic students to demonstrate their English language knowledge and skills in both internal and 
external language tests. Finally, it could be extended into a large scale research programme on the validity of the different types of test accommodations offered for testing SEN and non-SEN EFL students.

\section{REFERENCES}

Adams M., Bell L. A. (2016), Teaching for Diversity and Social Justice. New York: Routledge, Taylor \& Francis.

ADE. Arkansas Department of Education (2005), Guidelines for Assessment Accommodations For Students with Disabilities. Special Education Unit Arkansas Department of Education \& Academic Standards and Assessment Unit. Available from: https://arksped.k12.ar.us/ documents/ special projects/Guidelines\%20for\%20Assessment\%20Accommodations.pdf [Accessed 1st May 2019].

Arton M. (1998), The professionalisation of mental nursing in Great Britain, 1850-1 950.A Dissertation Submitted for the Degree of Doctor of Philosophy. University College London. Available from: http:// discovery.ucl. ac.uk/ 1317913/ [Accessed 28th M arch 2019].

Baglieri S., Shapiro A. (2012), Disability Studies and the Inclusive Classroom: Critical Practices for Creating Least Restrictive Attitudes. New York: Routledge. Bhattacharyya S., Clark M., J., H. (2013), Can You Hear Us? Voices Raised against Standardized Testing by Novice Teachers. „Creative Education”, No 4(10), pp. 633-639.

Bui X., Quirk C., Almazan S., Valent M. (2010), Inclusive Education Research \& Practice. Inclusion works! Maryland Coalition for Inclusive Education, pp. 1-14. Available from: http://www.mcie.org/site/usermedia/applic ation/11/inclusion-works-(2010).pdf [Accessed 25th M arch 2019].

Clarkson J., Coleman R., Hosking I., Waller S. (2007), Inclusive design toolkit.

Cambridge: Engineering Design Centre.

Darrow A. (2007), Adaptations in the Classroom: Accommodations and modifications: Part I. „General M usic Today”, No 20(3), pp. 32-34.

Dijkers M. (2015), What is a Scoping Review?. „KT Update”, No 4(1), pp. 1-5.

Dolan R. P., Hall T. E., Banerjee M., Chun E., Strangman N. (2005), Applying principles of universal design to test delivery: The effect of computerbased read-aloud on test performance of high school students with learning disabilities. "J ournal of Technology, Learning, and Assessment", No 3 (7), pp. 4-31. Available from: http://www.jtla.org https://ejournals. bc.edu/index.php/jtla/article/view/1660/1496 [Accessed 20th April 2019].

Dolezalek H., Sayre R. (2009), Standardized testing in schools. Edina, Minn: ABDO Pub. Co. 
EEAS European External Action Service (2018), The European Union at the United Nations, fact sheet. Available from: https://eeas.europa.eu/head quarters/headquarters-homepage/9875/ european-union-united-natio ns_en [Accessed 2nd M ay 2019].

EDF. European Disability Forum. (2019), Design for all. Available from: http:// www.edf-feph.org/design-all [Accessed 6th May 2016].

EIDD Design for All Europe (2004), Stockholm Declaration. Adopted on 9 M ay 2004, at the Annual General Meeting of the European Institute for Design and Disability in Stockholm. Design for All Europe. Retrieved from http://dfaeurope.eu/what-is-dfa/dfa-documents/the-eidd-stockholm-dec laration-2004/

European Commission. (2017), The European Pillar of Social Rights in 20 principles. Available from: https://ec.europa.eu/commission/priorities/deeper -and-fairer-economic-and-monetary-union/european-pillar-social-rights/ european-pillar-social-rights-20-principles en [Accessed 4th M ay 2019]. Evans S. F., Howarth, M . (2019), I am happy, so I learn it: The ethical dilemma of choosing to promote happiness in an educational world of standards, (in:) Keough, P. D. (ed.), Ethical Problem-Solving and Decision-Making for Positive and Conclusive Outcomes. Hershey: IGI Global, pp 101-122.

Finkelstein S., Sharma U., Furlonger B. (2019), The inclusive practices of classroom teachers: a scoping review and thematic analysis. "International Journal of Inclusive Education", pp. 1-28. DOI: 10.1080/13603116.2019.1572232

Gordon K. A., Garcia-Nevarez A., Roundtree H. W. J., Valero-Kerrick A. (2014), Early childhood education: Becoming a professional. Thousand Oaks, CA: SAGE Publications.

Haug P. (2017), Understanding inclusive education: ideals and reality. "Scandinavian J ournal of Disability Research", No19(3), pp. 206-217.

Karten T. J. (2015), Inclusion Strategies That Work!: Research-Based M ethods for the Classroom. Los Angeles: SAGE Publications.

Kearney K. (1996), Highly Gifted Children in Full Inclusion Classrooms. „Highly Gifted Children", No 12(4), pp. 2-11. Available from: https://files.eric. ed.gov/fulltext/ED425575.pdf [Accessed 22nd April 2019].

Kisanji J. (1999), Historical and theoretical basis of inclusive education, keynote address for the Workshop on Inclusive Education in Namibia: The Challenge for Teacher Education, 24- 25 M arch 1999, Rossing Foundation, Khomasdal, Windhoek, Namibia. Available from: https:// www.eenet.or g.uk/resources/docs/hist_theorectic.doc [Accessed 15th April 2019].

Lawrence-Brown D., Sapon-Shevin M. (eds.) (2015), Condition Critical: Key Principles for Equitable and Inclusive Education. New York: Teachers College Press. 
Łodej M. (2016), Dyslexia in first and foreign language learning: a cross-linguistic approach. Newcastle upon Tyne: Cambridge Scholars Publishing. Myerson J., Bichard J.-A., Erlich A. (2016), New Demographics New Workspace: Office Design for the Changing Workforce. New York: Routledge. M cLeskey J., M aheady L., Billingsley B., Brownell M. T., Lewis T. J. (eds.) (2019), High Leverage Practices for Inclusive Classrooms. New York: Routledge. Merijer C., Soriano V., Waltkins A. (eds.) (2003), Special Needs Education in Europe. Thematic Publication. Denmark: European Agency for Development in Special Needs Education.

NDA. National Disability Authority. (2019), The seven principles. Dublin: Center for Excellence in Universal Design. Available from: http:// universaldesig n.ie/What-is-Universal-Design/The-7-Principles/ [Accessed 26th April 2019]. Nes K., Strømstad M . (2003), Developing Inclusive Teacher Education. New York: Routledge. Available from: https://epdf.tips/ developing-inclusive-teache r-education.html [Accessed 19th April 2019].

OECD (2012), PISA 2009. Technical Report. Paris: OECD Publishing. Available from: https://www.oecd.org/pisa/ pisaproducts/PISA-2012-technical-r eport-final.pdf [Accessed 5th May 2019].

Persson H., Ahman H., Yngling A., Gulliksen J. (2014), Universal design, inclusive design, accessible design, design for all: different concepts-one goal? On the concept of accessibility-historical, methodological and philosophical aspects. „Universal Access in the Information Society”, No 14(4), pp. 505-526.

Pfeiffer S. I., Reddy L A. (eds.) (1999), Inclusion practices with special needs students: Theory, research, and application. Bringhamton: Howarth Press.

Pohl S., Südkamp A., Hardt K., Carstensen C. H., Weinert S. (2016). Testing Students with Special Educational Needs in Large-Scale Assessments - Psychometric Properties of Test Scores and Associations with Test Taking Behavior. „Frontiers in Psychology”, No 7 (154), pp. 1-14.

Reddy L. A. (2012), Inclusion of disabled children and school reform: a historical perspective, (in:) Pfeiffer, S. I., Reddy, L. A. (eds.), Inclusion practices with special needs students: Theory, research, and application. Bringhamton: Haworth Press, pp. 3-24.

Richardson B., Wheeless L. R. (2009), Teachers tattling on teachers. Policy attitude and tenuer's influence on peer reporting of unethical behavior. "International Journal of Educational Reform", No 18(1), pp. 46-62.

Smith M. L. (1991), Put to the test: The effects of external testing on teachers. „Educational Researcher", No 20, pp. 8-11.

Steinfeld E. (2010), Advancing Universal Design(in)M aisel, J. L. (ed.), The state of the science in universal design: Emerging research and developments. Sharjah, U.A.E.: Bentham Science Publishers, pp. 1- 19. 
The Glossary of Education Reform. (2015), Standardized test. Available from: from https:// www.edglossary.org/standardized-test/ [Accessed 13th M ay 2019].

The United Nations (1948), Universal declaration of human rights. Available from: https:// www.un.org/en/ universal-declaration-human-rights/ [Accessed 6th May 2019].

Twachtman-Cullen D., Twachtman-Bassett J. (2011), The IEP from A to Z: How to create meaningful and measurable goals and objectives. San Francisco, Calif: Jossey-Bass.

UNESCO (1994). The Salamanca Statement and Framework for Action on Special Needs Education. Paris: UNESCO. Available from: http:// www.unesc 0.org/education/pdf/SALAM A_E.PDF [Accessed 1st M ay 2019].

Wallace M. W., Irons E. J. (2010), The lived experience of public school teachers: Novice to expert. „National Social Science J ournal”, No 33, pp. 166- 172.

Watkins A. (2009), Key principles for promoting quality in inclusive education. Recommendations for policy makers. Odense, Denmark: European Agency for Development in Special Needs Education. 


\section{APPENDIX A}

A mapping alignment between Principles of Inclusive Design and Type of Test Accommodations (after Steinfeld, 2010: 2, NDA, 2012, and ADE, 2005: 3-4).

\begin{tabular}{|c|c|c|c|c|c|}
\hline $\begin{array}{l}\text { Principle } \\
\text { of Inclusive Design }\end{array}$ & Description & Guidelines & \begin{tabular}{|l|} 
Type of Test \\
Accommodations
\end{tabular} & Description & Guidelines \\
\hline 1. Equitable Use & $\begin{array}{l}\text { The design is useful and marketable } \\
\text { to people with diverse abilities. }\end{array}$ & $\begin{array}{l}\text { 1a. Provide the same means of use for all users: identical } \\
\text { whenever possible; equivalent when not. } \\
\text { 1b. Avoid segregating or stigmatizing any users. } \\
\text { 1c. Provisions for privacy, security, and safety should be } \\
\text { equally available to all users. } \\
\text { 1d. Make the design appealing to all users. }\end{array}$ & \begin{tabular}{|l|} 
A. Presentation \\
Accommodations \\
\end{tabular} & $\begin{array}{l}\text { Allow students to access information in } \\
\text { ways that do not require them to visually } \\
\text { read standard print. These alternate modes } \\
\text { of access include visual, auditory and } \\
\text { a combination of visual and auditory. }\end{array}$ & $\begin{array}{l}\text { A1. Increase spacing between test items. } \\
\text { A2. Use non-serif font, size 12pp. and larger. } \\
\text { A3. Limit number of visual distractors. } \\
\text { A4. Provide visual cues when possible. } \\
\text { A5. Change layout so the task is processed in linear } \\
\text { and left-to right mode. } \\
\text { A6. Provide on-task/ focusing prompts. }\end{array}$ \\
\hline $\begin{array}{l}\text { 2. Flexibility in } \\
\text { Use }\end{array}$ & $\begin{array}{l}\text { The design accommodates a wide } \\
\text { range of individual preferences and } \\
\text { abilities. }\end{array}$ & $\begin{array}{l}\text { 2a. Provide choice in methods of use. } \\
\text { 2b. Accommodate right- or left-handed access and use. } \\
\text { 2c. Facilitate the user's accuracy and precision. } \\
\text { 2d. Provide adaptability to the user's pace. }\end{array}$ & $\begin{array}{l}\text { B. Response } \\
\text { Accommodations }\end{array}$ & $\begin{array}{l}\text { Allow students to complete assignments, } \\
\text { tests and activities in different ways or to } \\
\text { solve or organize problems using some } \\
\text { type of assistive device. }\end{array}$ & $\begin{array}{l}\text { B1. Allow answers to be circled or traced } \\
\text { instead of written when applicable. } \\
\text { B2. Allow templates. } \\
\text { B3. Permit answers to be recorded directly into } \\
\text { test booklet. } \\
\text { B4. M onitor placement of student responses on } \\
\text { answer sheet. }\end{array}$ \\
\hline $\begin{array}{l}\text { 3. Simple and } \\
\text { Intuitive Use }\end{array}$ & $\begin{array}{l}\text { Use of the design is easy to under- } \\
\text { stand, regardless of the user's expe- } \\
\text { rience, knowledge, language skills, } \\
\text { or current concentration level. }\end{array}$ & $\begin{array}{l}\text { 3a. Eliminate unnecessary complexity. } \\
\text { 3b. Be consistent with user expectations and intuition. } \\
\text { 3c. Accommodatea widerange of literacy and languageskills. } \\
\text { 3d. Arrange information consistent with its importance. } \\
\text { 3e. Provide effective prompting and feedback during } \\
\text { and after task completion. }\end{array}$ & $\begin{array}{l}\text { C. Timing/sched- } \\
\text { uling Accommo- } \\
\text { dations }\end{array}$ & $\begin{array}{l}\text { Change the allowable length of a test or } \\
\text { assignment and may also change the way } \\
\text { the time is structured due to the individual } \\
\text { /physical needs of some students. }\end{array}$ & $\begin{array}{l}\text { C1. Extend allotted time for a test. } \\
\text { C2. Break large assignments into smaller tasks. } \\
\text { C3. Allow frequent breaks. } \\
\text { C4. Allow subtests to be taken in a different order. }\end{array}$ \\
\hline $\begin{array}{l}\text { 4.Perceptible } \\
\text { Information }\end{array}$ & $\begin{array}{l}\text { The design communicates necessary } \\
\text { information effectively to the user, } \\
\text { regardless of ambient conditions or } \\
\text { the user's sensory abilities. }\end{array}$ & $\begin{array}{l}\text { 4a. Use different modes (pictorial, verbal, tactile) for re- } \\
\text { dundant presentation of essential information. } \\
\text { 4b. Provide adequate contrast between essential infor- } \\
\text { mation and its surroundings. } \\
\text { 4c. M aximize "legibility" of essential information. } \\
\text { 4d. Differentiate elements in ways that can be described } \\
\text { (i.e., make it easy to give instructions or directions). } \\
\text { 4e. Provide compatibility with a variety of techniques or } \\
\text { devices used by people with sensory limitations. }\end{array}$ & D. Setting & $\begin{array}{l}\text { Change the location in which a test or as- } \\
\text { signment is given or the conditions of the } \\
\text { assessment setting. }\end{array}$ & $\begin{array}{l}\text { D1. Change location to reduce distractions. } \\
\text { D2. Change location so student does not distract } \\
\text { others. } \\
\text { D3. Change location to access special equipment } \\
\text { D4. Change location to have a test in small group } \\
\text { setting. }\end{array}$ \\
\hline $\begin{array}{l}\text { 5.Tolerance for } \\
\text { Error }\end{array}$ & $\begin{array}{l}\text { The design minimizes hazards and } \\
\text { the adverse consequences of acci- } \\
\text { dental or unintended actions. }\end{array}$ & $\begin{array}{l}\text { 5a. Arrange elements to minimize hazards and errors: } \\
\text { most used elements, most accessible; hazardous ele- } \\
\text { ments eliminated, isolated, or shielded. } \\
\text { 5b. Provide warnings of hazards and errors. } \\
\text { 5c. Provide fail safe features. } \\
\text { 5d. Discourage unconsciousactionintasksthatrequirevigilance. }\end{array}$ & & & \\
\hline
\end{tabular}




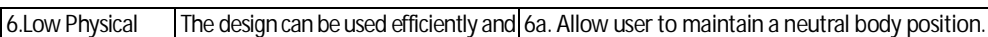

Effort

comfortably and with a minimum of $6 \mathrm{~b}$. Use reasonable operating forces.

fatigue.

$6 c$. M inimize repetitive actions.

6d. Minimize sustained physical effort.

7. Size and Space Appropriate size and space is pro- 7 a. Provide a clear line of sight to important elements for Approach and vided for approach, reach, manipula- for any seated or standing user.

tion, and use regardless of user's $7 \mathrm{~b}$. Make reach to all components

body size, posture, or mobility. seated or standing user.

7c. Accommodate variations in hand and grip size.

7d. Provide adequate space for the use of assistive devices or personal assistance.

\begin{tabular}{|l|l|l|}
\hline & & \\
\hline & & \\
\hline & & \\
\hline
\end{tabular}




\section{APPENDIX B}

\section{A mapping alignment between Type of Test Accommodations and Areas of Weaknesses in Dyslexia \\ (after ADE, 2005: 3-4, and Łodej 2016: 3-6).}

\begin{tabular}{|c|c|c|c|c|c|}
\hline \begin{tabular}{|l|} 
Type of Test \\
Accommodations
\end{tabular} & Description & Guidelines & \begin{tabular}{|l|} 
Areas of Weak- \\
nesses in Dyslexia
\end{tabular} & Description & Guidelines \\
\hline $\begin{array}{l}\text { A. Presentation } \\
\text { Accommodations }\end{array}$ & $\begin{array}{l}\text { Allow students to accessinformation } \\
\text { in ways that do not require them to } \\
\text { visually read standard print. These } \\
\text { alternate modes of access include } \\
\text { visual, auditory and a combination } \\
\text { of visual and auditory. }\end{array}$ & $\begin{array}{l}\text { A1. Increase spacing between test items } \\
\text { A2. Use non-serif font, size 12pp. and larger } \\
\text { A3. Limit number of visual distractors } \\
\text { A4. Provide visual cues when possible } \\
\text { A5. Change layout so the task is processed in linear } \\
\text { and left-to right mode. } \\
\text { A6. Provide on-task/ focusing prompts. }\end{array}$ & $\begin{array}{l}\text { I. Short term } \\
\text { memory }\end{array}$ & $\begin{array}{l}\text { Poor short term memory causes problems } \\
\text { with copying down correctly, } \\
\text { keeping track of ideas when speaking, lis- } \\
\text { tening or writing, } \\
\text { following the sense of a passage while } \\
\text { reading, } \\
\text { multi-tasking. }\end{array}$ & $\begin{array}{l}\text { IA. Reduce elements that can interfere with short } \\
\text { term and working memory. } \\
\text { IB. Provide memory aids and visual supports. } \\
\text { IC. Breakinformation into smaller instructional units. } \\
\text { ID. Reword instructions, use short sentences. } \\
\text { IE. Shorten reading assignments } \\
\text { IF. Offer a spelling bank. }\end{array}$ \\
\hline $\begin{array}{l}\text { B. Response } \\
\text { Accommodations }\end{array}$ & $\begin{array}{l}\text { Allow students to complete assign- } \\
\text { ments, tests and activities in differ- } \\
\text { ent ways or to solve or organize } \\
\text { problems using some type of } \\
\text { assistive device. }\end{array}$ & $\begin{array}{l}\text { B1. Allow answers to be circled or traced } \\
\text { instead of written when applicable. } \\
\text { B2. Allow templates. } \\
\text { B3. Permit answers to be recorded directly into test } \\
\text { booklet. } \\
\text { B4. Monitor placement of student responses on an- } \\
\text { swer sheet. }\end{array}$ & $\begin{array}{l}\text { II. Phonological } \\
\text { skills (recognizing, } \\
\text { pronouncing, } \\
\text { sequencing } \\
\text { sounds) }\end{array}$ & $\begin{array}{l}\text { Poor phonological skills cause problems } \\
\text { with spelling, understanding long words, } \\
\text { saying long words, reading accuracy. }\end{array}$ & $\begin{array}{l}\text { IIA. Pair visuals with oral instructions. } \\
\text { IIB. Use highlighting key words/concepts. } \\
\text { IIIC. Reduce spelling tests. }\end{array}$ \\
\hline $\begin{array}{l}\text { C. Timing/sched- } \\
\text { uling Accommo- } \\
\text { dations }\end{array}$ & $\begin{array}{l}\text { Change the allowable length of a test } \\
\text { or assignment and possiblyalso change } \\
\text { the way the time is structured due to } \\
\text { the individual/physical needs of some } \\
\text { students. }\end{array}$ & $\begin{array}{l}\text { C1. Extend timeallotted for a test. } \\
\text { C2. Break large assignments into smaller tasks. } \\
\text { C3. Allow frequent breaks. } \\
\text { C4. Allow subtests to be taken in a different order. }\end{array}$ & $\begin{array}{l}\text { III. Sequencing and } \\
\text { structuring } \\
\text { information }\end{array}$ & $\begin{array}{l}\text { Difficulty with sequencing and structuring } \\
\text { information causes problems with writing } \\
\text { and copying words accurately, following } \\
\text { and understanding instructions, structur- } \\
\text { ing essay, taking clear notes, filling in, carry- } \\
\text { ing out tasks in an efficient and logical way. }\end{array}$ & $\begin{array}{l}\text { IIIA. Use the cloze method. } \\
\text { IIIB. Provide templates. } \\
\text { IIIC. Allow the use of assistive technology. }\end{array}$ \\
\hline \multirow[t]{2}{*}{\begin{tabular}{|l|} 
D. Setting \\
Accommodations
\end{tabular}} & $\begin{array}{l}\text { Change the location in which a test } \\
\text { or assignment is given or the condi- } \\
\text { tions of the assessment setting. }\end{array}$ & $\begin{array}{l}\text { D1. Change location to reduce distractions. } \\
\text { D2. Change location so student does not distract others. } \\
\text { D3. Change location to access special equipment } \\
\text { D4. Change location to have a test in small group setting. }\end{array}$ & IV. Perception & $\begin{array}{l}\text { Poor visual perception causes problems } \\
\text { with losing the place while reading, miss- } \\
\text { ing out words or lines, ignoring diacritics, } \\
\text { rereading/skipping lines, misreading words. }\end{array}$ & $\begin{array}{l}\text { IVA. Reduce extraneous visual stimuli on a page by } \\
\text { highlighting the target stimulus. } \\
\text { IVB. Provide visual markers to guide the student. } \\
\text { IVC. Provide a model to which the student can re- } \\
\text { fer when completing tasks } \\
\text { IVD. Reduce the visual clutter in worksheets. }\end{array}$ \\
\hline & & & V. Movement & $\begin{array}{l}\text { Difficulty with motor skills can result with } \\
\text { slow and untidy handwriting, poor presen- } \\
\text { tation of written work. }\end{array}$ & $\begin{array}{l}\text { VA. Allow access to a computer. } \\
\text { VB. Avoid scantrons. }\end{array}$ \\
\hline
\end{tabular}

